\title{
The impact that has had the quality management, on the competitiveness of organizations
}

\section{El impacto que ha tenido la gestión de la calidad, en la competitividad de las organizaciones}

\author{
QUIROZ-VELÁZQUEZ, Manuela Elvia† \& RAMIREZ-HERNÁNDEZ, Marivel
}

Instituto Tecnológico de Toluca. Departamento de Ciencias Económico-Administrativas

ID $1^{\text {st }}$ Author: Manuela Elvia, Quiroz-Velázquez / ORC ID: 0000-0001-8294-5670

ID $1^{\text {st }}$ Coauthor: Marivel, Ramirez-Hernández / ORC ID: 0000-0001-8767-6860

DOI: $10.35429 / J E S .2019 .5 .3 .9 .17$

Received August 12, 2019; Accepted December 01, 2019

\begin{abstract}
Overview of quality management systems are essential for the competitiveness of the organizations, since they allow to promote a culture of continuous improvement in the same, higher education institutions are not exempt and is for this reason that they have implemented these systems as in the Nacional Tecnológico de Mexico, which currently has a comprehensive system (System of management of quality (ISO 9001:2015), environmental management (ISO 14001:2015) system, equity of gender (MEG), system model Energy management, health and safety at work management system, recognition of Social responsibility and in some cases the institutional environmental programme (PAI), for it is important to know how they have impacted the community. Some findings about the management system in the Instituto Tecnológico de Toluca, is that, if there is knowledge of the processes, care of environment due to institutional environmental program
\end{abstract}

Organizations, Quality, Competitiveness

\begin{abstract}
Resumen
Los sistemas de gestión de calidad son imprescindibles para la competitividad de las organizaciones, ya que permiten fomentar la cultura de mejora continua en las mismas, las Instituciones de Educación Superior no están exentas y es por ello que se han implementado estos sistemas como en el Tecnológico Nacional de México, Institución que actualmente cuenta con un sistema integral Sistema de Gestión de Calidad (ISO 9001:2015), Sistema de Gestión Ambiental (ISO 14001:2015), Modelo de equidad de Género (MEG), Sistema de Gestión de Energía, Sistema de Gestión de Salud y Seguridad en el Trabajo, Reconocimiento a la Responsabilidad Social y en algunos casos el Programa Ambiental Institucional (PAI), para ello es importante conocer como han impactado en la comunidad tecnológica. Algunos hallazgos sobre el sistema de gestión en el Instituto Tecnológico de Toluca, es que, si existe conocimiento de los procesos, cuidado de medio ambiente debido al Programa Ambiental Institucional y al sistema de gestión ambiental ISO 14001:2015 sin embargo, aún existen oportunidades de mejora en las actividades que se realizan en la organización, como la participación y concientización de la comunidad tecnológica constituida por docentes, estudiantes y personal de apoyo a la educación.
\end{abstract}

Organizaciones, Calidad, Competitividad

Citation: QUIROZ-VELÁZQUEZ, Manuela Elvia \& RAMIREZ-HERNÁNDEZ, Marivel. The impact that has had the quality management, on the competitiveness of organizations. Journal-Economic Systems. 2019. 3-5: 9-17

$\dagger$ Researcher contributing as first author. 


\section{Introduction}

This article presents a different way of evaluating quality management systems since within the best known models are audits, the use of indicators and SERVQUAL as the most used. In this sense, the evaluation is done to diagnose the impact of Quality Management Systems (QMS) in a Higher Education Institution represented by the National Technological Institute of Mexico, made up of 260 decentralized and centralized Technological Institutes.

To carry out this study, the case study of the Technological Institute of Toluca was used, which has implemented an integral system in addition to the Integral Environmental Program (PAI), and the questionnaire for the application of semi-structured interviews to those responsible for the systems was also designed. of management, teachers, students and alumni.

With the objective of identifying the opinion regarding the aforementioned management systems. The qualitative method for the realization of this research project has been used in some cases, since quantitative methods are used more frequently, here the importance of using the method and its wealth, with the support of ATLAS IT software (software used to analyze documentary information and interviews).

The results allowed us to know the situation of the management systems, from the point of view of the actors, mainly those responsible for the management systems of the Technological Institute of Toluca, the teachers who teach some of the learning units related in a way Indirect with any of the management systems, as well as the students currently studying some of the careers in this Institution, graduates of this Institution allowed us to know their opinions about the operationalization of the management systems.

The conclusions according to the results that in the Institutions of Higher Education as an example the Technological Institute of Toluca, management systems such as quality (ISO 9001: 2015, ISO 1400: 2015), as well as the Gender equity model and the Institutional Environmental Program are in a dynamic process that allows them to continuously improve.
As well as the Technological Institute has managed to establish the importance of management systems in the heads of each program, teachers of different careers, students and graduates.

The main recommendations mean that there is little dissemination and communication within, so that greater actions related to the dissemination and communication of management systems must be implemented, as well as encouraging the participation of the technological community, to generate awareness and awareness. Therefore, the planning, organization and implementation of different strategies for the improvement of quality management systems is necessary.

\section{Theoretical framework}

Quality is to translate the future needs of users into measurable characteristics, only then can a product be designed and manufactured to satisfy a price that the customer will pay; Quality can be defined only in terms of the agent. The word quality has multiple meanings. Two of them are the most representative: Quality consists of those product characteristics that are based on customer needs and therefore provide product satisfaction; Quality consists of freedom after deficiencies (Juran, 1990)

In a brief way, quality means product quality. More specific, quality is work quality, service quality, information quality, process quality, people quality, system quality, company quality, quality of objectives. "Quality is compliance with the requirements. The requirements must be clearly established so that there are no misunderstandings; the measurements must be taken continuously to determine compliance with those requirements; the nonconformity detected is an absence of quality" (Alexander, 2002) following:

The factors proposed by Ishikawa are the

- $\quad$ The customer is the most important.

- We must prevent, not correct.

- $\quad$ Reduce costs and waste in general.

- $\quad$ Long term results. No short paths to achieve quality.

Participation and involvement of all members. 
- $\quad$ You have to work in a team.

- Measure results.

- Give recognition.

- $\quad$ The commitment and support of senior management is required.

Institute effective and intense training and development programs.

Create awareness of the need.

Have a process and tool for permanent improvement. From this last point, Ishikawa managed to define a technical philosophy that is part of the quality, he called it the seven statistical tools of the administration for the analysis of problems such as:

\author{
1. Pareto chart. \\ 2. Cause and effect diagram. \\ 3. Stratification. \\ 4. Verification sheet. \\ $5 . \quad$ Histograms. \\ 6. Scatter diagrams. \\ 7. Graphs and control panels. (Ishiwawa, \\ 1986)
}

\section{Quality, strategic matter}

Total quality management (GCT) is not a current fad that will disappear tomorrow. The GCT is a strategic business issue that affects customer satisfaction, market share and business profit. The GCT implies ensuring that the company does the right thing at the first and at all times. It goes beyond ensuring the suitability of a service or product, since it makes possible a comprehensive management of added value by meeting and exceeding customer expectations.

Therefore, the GCT requires the personal attention of the first executive and his leadership; This is an issue that is too important to be left to functional experts.

The GCT is a strategic issue, because:

World market competition has never been so tough.

Companies that increase their market shares are those that offer the best relationship between customer value and price.

The best value for money comes from a competitive quality at a competitive price (Duque Olivas, 2005)
One of the best known quality management systems worldwide is the ISO (International Standards Organization) which since 1947 is an independent, non-governmental organization with a membership of 162 national standards bodies, through its members brings together Experts to share knowledge and develop voluntary international standards based on consensus and relevant to the market, that support innovation and provide solutions to global challenges, the Central Secretariat is in Geneva, Switzerland (ISO, 2017)

ISO management systems allow a systems approach, however one of the criticisms is that these systems have a high cost in their planning, organization, management and control, as well as their competitive vision rather than sustainable except ISO 14001; Another aspect is that these systems are implemented in large transnational companies and these production patterns have influenced so that the countries of the region integrated to globalization, adopt environmental incorporations to their productive processes in accordance with the guidelines originated in the countries from North.

Similar to what is happening in developed countries, certification policies have spread throughout the region, mainly through ISO 14000 standards.

This certification is carried out through environmental companies that prepare industries and others that carry them out.

There have been no real evaluations of the efficiency of the processes, but there are already serious questions about the real impact of them, many certification companies act through subsidiaries, the control of the efficiency and the seriousness of these is very variable, which puts a mantle of doubt about the quality and veracity of any of the certifications.

On the other hand, there are many national certifications made based on environmental regulations and some based on the principle of gradualness to incorporate environmental standards, they have very lax and distant standards of international standards (Giglio, 2006) 


\section{Quality management systems in the educational system: National technology of mexico}

One of the relevant aspects in studies that relate to Higher Education Institutions in Mexico (HEI) is that many of them work under a systems approach, since their administration seen under this systemic school, considers HEI as a set of parts, so associated, that forms a coherent whole or unity according to Münch (2014); One of the Higher Education Institutions (IES) is the Tecnológico Nacional de México (TecNM); It is constituted by 260 Technological Institutes with a centralized and decentralized character, both of which depend on the Ministry of Public Education, of which 126 are federal Technological Institutes and 134 are Decentralized Technological Institutes, 4 Team Optimization and Development Centers (CRODES), a Center Interdisciplinary Research and Teaching in Technical Education (CIIDET) and a National Center for Research and Technological Development (CENIDET). The TecNM is a Higher Education system that serves 521,105 among the students of the 41 undergraduate and Postgraduate degrees (TECNM, 2013-2018)

The System of Technological Institutes in a national network of HEI and the objectives are aligned to the National Development Plan 2013-2018 where the objectives and strategies are established to be carried out at all educational levels. In the current Development plan, it is considered that education must be of quality and specifically in Strategy 3.5.3, it refers to promoting the development of local scientific, technological and innovation vocations and capacities, to strengthen sustainable regional development and inclusive, so they were integrated into different lines of action such as:

a) The design of differentiated public policies that allow the promotion of scientific and technological progress in regions and federal entities, based on their economic vocations and local capacities.

b) Promotion of the formation of high-level human resources, associated with the development needs of the federative entities according to their vocations.

c) Support for the establishment of scientific-technological ecosystems that favor regional development. d) Increase investment in Total Intellectual Capital (CTI) at state and regional level with the concurrence of the different areas of government and sectors of society. (; PND, 2013-2018)

It should be noted that within points a) and b) mentioned above and according to what was stated in the PND there should be differentiated educational policies regarding academic levels, regions and / or territories; However, in reality only an educational policy was established as a guideline for all academic levels without differentiating regions and territories either. The system analyzed is the Tecnológico Nacional de México (TecNM), within the vision of TecNM there is a focus on sustainability since it considers the following: To be one of the pillars of the nation's sustainable, sustainable and equitable development. Likewise, in the mission: Offer quality technological higher education services, with relevant and equitable national coverage, which contributes to the formation of a just and humane society, with a sustainability perspective.

In addition, the TecNM has different management processes that allow it to address academic, linkage and financial aspects to achieve the objectives, strategies, lines of action and indicators with which they were defined in the National Development Plan (2013-2018) and in the Education Sector Program 2013-2018 (SEP, 2013). Which were based on six strategic objectives aimed at achieving goals within the program; The objectives are:

1. Strengthen the quality of educational services

2. Increase coverage, promote inclusion and educational equity

3. Promote the integral formation of students

4. Boost science, technology and innovation

5. Strengthen the link with the public, social and private sectors; as well as

6. Modernize institutional management with transparency and accountability. In this last strategic objective, it is committed to increasing certified units and centers, as well as modernizing institutional management, strengthening transparency and accountability. 
The TecNM has several ISO 9001: 2015 Quality Management systems; The ISO 1400: 2015 Environmental Care Management System and some technology companies also have the Institutional Environmental Program (MYP), the Gender Equality Model or Gender Equality and Non-Discrimination System (SGIG) better known as MEG. The TecNM has established its commitment to mainstreaming the gender perspective as a strategic element to advance the incorporation of the perspectives of labor equality and non-discrimination, as well as the eradication of gender violence from its headquarters, Institutes, units and centers. To this end, the TecNM Gender Equality and NonDiscrimination Management System manual has been established (SGEG/TECNM, 2017). In the TecNM the information of the Quality Management Systems is centralized through the corresponding Department, whose main function is to work for continuous improvement and its planning, organization, direction and control is carried out by the Quality Manager, and is in coordination with the head of each Technological; which entails having a series of human, material and financial resources. The objectives and goals must be aligned to the Interinstitutional Development Program (PIID) as well as its budget is reflected in the Annual Operational Program (POA) so it is a way to control the results

It is also worth mentioning within the strategies of the National Development Plan in relation to the issue of sustainability, the TecNM has set some objectives that allow them to be fulfilled; That is why he has participated with the National Association of Universities and Institutions of Higher Education (ANUIES) and with the Ministry of Environment and Natural Resources (SEMARNAT) and with the National Institute of Ecology (INE) for the conformation of Institutional Environmental Plans (PAI). In the first phase an environmental training course was invited to 144 Higher Education Institutions (IES) belonging to the National Association of Universities and Institutions of Higher Education (ANUIES) of which 100 attended the call, but only 44 participated and complied with the development of the EPI; among which the following Technological Institutes participated: I.T. Tijuana, I.T. Sonora, I.T. Cd. Madero, I.T. Cd. Matamoros, I.T. Zacatecas, I.T. Colima, I.T. Aguascalientes, I.T. Puebla, I.T. Orizaba, I.T. Campeche, I.T. Minatitlán and the I.T. Toluca (Bravo, 2012).
The aforementioned plan; It was created to respond to the commitment made with the signing of the Earth Charter, consisting of carrying out actions in favor of the environment and strengthening the operations of the program for certification in ISO 14001, following the request of the SEMARNAT in the sense that the Higher Education Institutions (HEI) of the country must have an environmental program. The Institutional Environmental Program (PAI) constitutes an environmental education program that contemplates the management and use of waste generated by activities of the population within the educational institutions of the region. The objective of the EPI is to sensitize, raise awareness and educate the technology community, its content is a management plan (which contains procedures, actions, controls until reaching the results). The activities carried out are internal and external (inside and outside the facilities), donation and coordination of containers for the collection of batteries, the collection of paper, PET and solid waste, its collection is given by others organizations for the purpose of reuse, storage or final disposal. Other actions that the EPI contains, in which authorities from different institutions take part: State Commission of Natural Parks and Wildlife (CEPANAF), National Commission of Protected Natural Areas (CONANP) for the contribution to the care and restoration of the Nevado de Parque Nacional de Nevado de Toluca and the Sierra Morelos park, which together with the active participation of members of the technological community collaborate with the maintenance of green areas. There are several actions that are contemplated in the Institutional Environmental Program such as those mentioned above, where students of different engineering are integrated, for the release of their social service, as well as support in the preparation of studies and projects related to the subject of environment for the release of professional residences and Master's thesis in Environmental Engineering Sciences and the Doctorate in Environmental Sciences such actions are examples of sustainable activities that are carried out at the Technological Institute of Toluca.

That is why, you have the following research questions: What has been the impact of management systems in the organization called Tecnológico Nacional de México? What has been the impact of the Integral management system on a Technological as a case study?

QUIROZ-VELÁZQUEZ, Manuela Elvia \& RAMIREZ-HERNÁNDEZ Marivel. The impact that has had the quality management, on the competitiveness of organizations. Journal-Economic Systems. 2019 


\section{Overall Objective:}

To explore the impact of quality management practices in the Technological National of Mexico through a case study: Instituto Tecnológico de Toluca

\section{Specific Objectives:}

- Determine the qualitative method to identify the perception that the technological community has regarding the integral management system

- $\quad$ Apply the tools and determine the results

- $\quad$ Make recommendations for the quality management system.

\section{Methodology}

The qualitative research method tries to know the facts, processes, structures and people as a whole and not measuring the elements; it uses procedures that make observation less comparable in time and in different cultural circumstances, getting closer to naturalness, that is, without manipulating or stimulating any element with respect to reality. (Garcia, 2015)

Another method used is the case study, it promotes the determination and analysis of solutions to the problems that arise, not only based on the most appropriate theories and in the history of the organization, but through the collective discussion that helps to develop the strategic, analytical and synthetic mentality that organizations require, thus obtaining security in the decisions made and in the conduct of staff (López, 1995)

The case study method is a valuable research tool and its greatest strength is that through it the behavior of the people involved in the studied phenomenon is measured and recorded (Martínez C. P., 2006)

In this way, the Technological Institute of Toluca was analyzed as a case study; since it is one of the Higher Education Institutions belonging to the TECNM system that has the Quality Management Systems (QMS), as well as the Institutional Environmental Program (MYP). Considering that the system is large (260 Institutes) and complex to be able to make some recommendations that are relevant.
Regarding the research techniques that were used are the following:

Documentary research is the collection of information in documentary sources such as: National Development Plan 2013-2018 (PND), Educational Sector Program (PSE), Institutional Program of Innovation and Development 20132018, as well as internal programs of the Technological Institute from Toluca. The SWOT Analysis, which consists of detecting strengths, opportunities, weaknesses and threats that can affect the achievement of the plans, the purpose of the SWOT is to convert weaknesses into strengths and threats into opportunities. It is based on the analysis of the environment and is based on statistical, economic and financial projections (Münch, 2014).

Because a SWOT was carried out for the TECNM and for the Technological Institute of Toluca, considering its strengths, opportunities, weaknesses and threats, analysis of the environment and thus project the alternatives to follow, as well as the strategies (see figure 1)

Another technique used was the semistructured interview; It allows flexibility in obtaining the information and that the interviewee has the freedom to express his opinion regarding how he sees the management systems in his Technological, and for this, the interviewees who are related to the management systems were chosen.

The informants were selected within a frame of reference based on the knowledge of the Environmental Management Systems such as: ISO 14001, ISO 9001, Institutional Environmental Program and the person in charge of the system of gender equity and equality as part of compliance with the institutional objectives, as well as the head of the Department of Technology Management and Linking

In order to carry out the qualitative analysis of the semi-structured interviews, the first part of the construction of the questionnaire is first and through the Atlas Ti program, it allows us to work the interviews and identify the citations, categories, memos and concepts; using citations and categories in the Atlas IT system, management systems, educational organization, quality, continuous improvement, sustainability were obtained. 


\section{Results}

Quality management systems, gender equity and those related to environmental aspects of the technological system known as the TecNM are considered as an integral, dynamic system with areas of opportunity for continuous improvement. The information that was collected in a documentary way, showed us how from the National Development Plan the national education policy is dictated and this is operationalized through the Educational Sector Plan and the Inter-Institutional Development Program (PIID) until the Institutional Program Annual are instruments that allow the operationalization of Management systems in the Technological Institute of Toluca.

Likewise, the information obtained with the personnel in charge of the management systems, informed us about their importance, the interrelations that exist between the systems and the areas of opportunity for their improvement and the possible participation of more teachers and students to achieve the objectives.

Teachers who participated in the interviews recognize the role that management systems currently have (from ISO 9001: 2015 to ISO 14001: 2015, which is being implemented), they believe that greater participation is required by academies and They determine that they need a greater relationship with those responsible for each system to improve communication.

In the case of students, participation in management systems; It occurs through various activities for the release of academic credits, social service and accreditation of professional residences, in relation to what they think of the systems, they consider them important for the Institute and could be an example for other educational Institutions, for this they consider that they also have areas of improvement and especially in the internal communication towards them.

The research project has been considered as a relevant aspect to continue the process of continuous improvement and especially for the generation of awareness as described by some managers of management systems, aware that they could reach excellence, not only for the achievement of objectives and goals; or compliance in audits, but to form a quality culture.

\section{Conclusions}

One of the first conclusions, related to compliance, application and operationalization of ISO standards in a Higher Educational Institution such as the Technological Institute of Toluca, allowed us to identify the impact that management systems have had on a qualitative level which represents

To know in depth the opinion that is had on these, this information was made known to us by those responsible for these systems, as well as the identification of the areas of opportunity that they currently have, on the part of the teachers determined that there are areas of interest and improve participation with those responsible for management systems, students recognize that they are part of an educational model that allows them to participate in quality management systems.

Regarding the qualitative method used, it should be noted that when conducting semistructured interviews, more information is obtained from the interviewees, resulting in a series of comments that are often limited in the survey responses.

It can be concluded according to the results; that, in the Technological Institute of Toluca, management systems such as quality (ISO 9001: 2015, ISO 1400: 2015), as well as the Gender equity model and the Institutional Environmental Program are in a dynamic process that It allows continuous improvement in both the actions and the participation of the technological community constituted by teachers, administrators and students.

The Technological Institute has also managed to establish the commitment of senior management, those responsible for each management system, the participation of teachers from different careers, as well as students and graduates.

\section{Recomendations}

The quality management systems at the Technological Institute of Toluca have supported the main operating processes (ISO 9001: 2008 and 2015). 
In addition to allowing the implementation of the other quality management systems such as ISO 14001: 2015 and those that are complementary but no less important, such as gender equity and constitute the integral system, as well as the Institutional Environmental Program (MYP) that has largely supported ISO 14001, however it is worth mentioning that when consulting In charge of these systems, they recognize that there are still many actions with the technological community due to the lack of communication, dissemination and involvement of the same, which makes them rethink the strategy to raise awareness among members of the technological community.

Likewise, when the technological community was interviewed, teachers who are immersed in these processes participate partially; that is to say in the academic process, but even with few actions, students also participate little in these processes either in academic activities and related to the MYP or indirectly to release certain academic credits, however, they recognize that they still need them more diffusion and greater participation. This constitutes a double effort for those responsible for management systems, on the one hand, what is requested in the corresponding audits and the generation of commitment and awareness by the technology community.

\section{References}

DUQUE, Olivas, E. (enero-junio de 2005). Revista de Ciencias Administrativas y Sociales. Obtenido de https://www.redalyc.org/pdf/818/81802505.pdf: https://www.redalyc.org/pdf/818/81802505.pdf

GARCÍA, M. R. (2015). Metodología de la Investigación. Ciencias Sociales . Ciudad de México : Trillas .

\section{GIGLIO}

(2006).

https://www.gestiopolis.com/cambio-

organizacional-y-calidad-total-en-la-argentina/. Obtenido de https://www.gestiopolis.com/cambio-

organizacional-y-calidad-total-en-la-argentina/.

HERNÁNDEZ, S. R., \& Fernández, C. C. (2014). Metodología de la Investigación. En S. R. Hernandez, Metodología de la Investigación (pág. 600). México: Mc Graw Hill Education.
ISHIKAWA, K. (1986). ¿Qué es el control total de la calidad? En K. Ishikawa, ¿Qué es el control total de calidad? (pág. 280). Bogotá: Norma.

ISO, I. (2017). Acerca de ISO. Acerca de ISO, 20-32.

JURAN, J. (1990). Juran y la planificación de la calidad . En J. Juran, Juran y la planificación de la calidad (pág. 380). Madrid : Diaz de Santos .

LÓPEZ, S. J. (1995). Las metodologías de estudios empresariales en España y México. Toluca, Estado de México: Universidad Autónoma del Estado de México.

MARTÍNEZ, A. B. (2015). Como organizar un trabajo de investigación . México: Lupus Magister .

MARTÍNEZ, C. P. (2006). El método de estudio de caso. Estrategia metodológica de la Investigación Científica . Pensamiento \& Gestión, 167.

MÜNCH, L. (2014). Administración gestión organizacional, enfoques y proceso administrativo . México: Pearson.

PAUL, R. e. (28 de mayo de 2019). La miniguía para el pensamiento crítico conceptos y herramientas. Obtenido de Fundación para el pensamiento crítico: www.criticalthinking.org

PIID, P. I.-2. (2013-2018). www.itspa.edu.mx/ wp-content/uploads/2018/01/PIID_2013-

2018_TECNM_Final.pdf . Obtenido de www.itspa.edu.mx/wp-content/uploads/2018/01 /PIID_2013-2018_TECNM_Final.pdf:

www.itspa.edu.mx/wp-content/uploads/2018/

01/PIID_2013-2018_TECNM_Final.pdf

PND, P. N. (2013-2018). www.pnd.gob.mx. Obtenido de www.pnd.gob.mx: http://www.pnd.gob.mx

SEP, S. D. (06 de 2013). file://C:/Users/HP14/Desktop/DOCTORADO/ PROGRAMA_SECTORIAL_DE_EDUCACIO N_2013_2018_WEB.compressed.pdf. Obtenido de

file://C:/Users/HP14/Desktop/DOCTORADO/ PROGRAMA_SECTORIAL_DE_EDUCACIO N_2013_2018_WEB.compressed.pdf: file:///C:/Users/HP14/Desktop/DOCTORADO/ PROGRAMA_SECTORIAL_DE_EDUCACIO N_2013_2018_WEB.compressed.pdf 
SGEG/TECNM. (23 de Febrero de 2017). Manual del SGIG y documentos. Obtenido de Manual y Documentos del Sistema de Gestión de Igualdad de Género y no Discriminación (SGIG): www.tecnm.mx/sgeg

TECNM, T. N. (21 de febrero de 2013-2018). www.tecnm.org.mx.

Obtenido

de

www.tecnm.org.mx: http://www.tecnm.org.mx 